IZA DP No. 7637

Wealth Distribution within Couples

Markus M. Grabka

Jan Marcus

Eva Sierminska

September 2013

Forschungsinstitut zur Zukunft der Arbeit Institute for the Study of Labor 


\title{
Wealth Distribution within Couples
}

\author{
Markus M. Grabka \\ DIW Berlin and TU Berlin
}

Jan Marcus

DIW Berlin

\author{
Eva Sierminska \\ CEPS/INSTEAD, \\ DIW Berlin and IZA
}

\section{Discussion Paper No. 7637 \\ September 2013}

\author{
IZA \\ P.O. Box 7240 \\ 53072 Bonn \\ Germany \\ Phone: +49-228-3894-0 \\ Fax: +49-228-3894-180 \\ E-mail: iza@iza.org
}

Any opinions expressed here are those of the author(s) and not those of IZA. Research published in this series may include views on policy, but the institute itself takes no institutional policy positions. The IZA research network is committed to the IZA Guiding Principles of Research Integrity.

The Institute for the Study of Labor (IZA) in Bonn is a local and virtual international research center and a place of communication between science, politics and business. IZA is an independent nonprofit organization supported by Deutsche Post Foundation. The center is associated with the University of Bonn and offers a stimulating research environment through its international network, workshops and conferences, data service, project support, research visits and doctoral program. IZA engages in (i) original and internationally competitive research in all fields of labor economics, (ii) development of policy concepts, and (iii) dissemination of research results and concepts to the interested public.

IZA Discussion Papers often represent preliminary work and are circulated to encourage discussion. Citation of such a paper should account for its provisional character. A revised version may be available directly from the author. 
IZA Discussion Paper No. 7637

September 2013

\section{ABSTRACT}

\section{Wealth Distribution within Couples}

While most studies on wealth inequality focus on the inequality between households, this paper examines the distribution of wealth within couples. For this purpose, we make use of unique individual level micro data from the German Socio-Economic Panel Study (SOEP). In married and cohabiting couples men's net worth, on average, is 33,000 euros higher than women's. We look at five different sets of factors (demographics, income, labor market, inheritances, financial decision-making in the partnership) that might explain this wealth gap. We find that all factors contribute to the explanation of the wealth gap within partnerships, with inheritances and income being particularly relevant. Furthermore, we find that specific characteristics (e.g., self-employment, no migration background, inheritances, high income) that decrease the wealth gap for women increase it for men. For men the respective coefficients are even stronger in absolute terms. When examining intra-partnership financial decision-making, we find the gap to be significantly smaller when the female partner manages the money and larger if the male partner has the last word in financial decisions.

JEL Classification: J2, D13, D31, D69, I31

Keywords: wealth gap, wealth inequality, intra-household allocation, gender, financial decision-making, SOEP

Corresponding author:

Eva Sierminska

CEPS/INSTEAD

3 , avenue de la Fonte

4364 Esch-sur-Alzette

Luxembourg

E-mail: eva.sierminska@ceps.lu 


\section{Introduction}

Welfare-oriented analyses of economic outcome measures such as income and wealth are typically carried out at the household level. These analyses assume that all members in a household pool and share their funds equally; i.e., all individuals exert similar control over "household resources.” Meanwhile, it is well known that household welfare and individual welfare are not the same (e.g., Phipps \& Burton 1995), although examining the distribution of the ownership of income and wealth in the household context is almost always hampered by the lack of individual-level data.

Thus, the inability to distinguish who owns the assets within the household has led many studies to focus on differences among family structures (e.g., Zagorsky 1999, Schmidt and Sevak 2006) and to rely on the implicit assumption of internal redistribution of wealth across members within a household. However, as shown by Frick et al. (2007) this assumption masks the "true" degree of inequality within households. Using households as the aggregation unit and applying per-capita household wealth to all household members yields a Gini coefficient for net worth of about .70, which is about $8 \%$ less than the one obtained from individual wealth information instead (.76). For a more top-sensitive inequality measure like the half squared coefficient of variation, this reduction is even greater at about $25 \%$.

Most studies of intra-household resource allocation have focused on consumption and income and found that it does matter whether the woman or the man has access to and/or control of resources. The more equal the access and control, the more balanced the income use and the household financial decisions. As most asset information is recorded at the household level, there are few studies examining the intra-household allocation of wealth (e.g., Lundberg and Ward-Batts 2000, Sunden and Surette 1998) and whether there exists a wealth gap within the household (Sierminska et al. 2010). Meanwhile, wealth affects the possibility for current and future consumption and is therefore central to measuring the well-being of households and their members.

Determining who controls assets within a household could be meaningful for several reasons. First, control of household assets provides individuals with greater access to resources and gives them a stronger negotiating position within the household. Second, unlike consumption decisions, which are typically lifestyle choices, decisions about savings and assets are crucial in determining the extent to which men and women are protected from unexpected events. Finally, it seems that control over assets could potentially be more important than control over income. Income matters when it is used for everyday spending. Accumulated wealth, on the other hand, may influence people's well-being for the entire period it is held, which could be a much longer period than for income. In addition, the way people manage and accumulate wealth will also determine their financial security during retirement. Given that women live longer and spend more years in retirement, it could be a desirable policy objective to see more savings and as a result more assets in the hands of women.

We make several contributions to the literature. First, we examine the distribution of wealth within couples (married and cohabiting), an issue that has been almost impossible to explore in the literature to date. To this end we make use of the 2007 wave of the German Socio-Economic Panel (SOEP), which includes unique micro data on individual wealth as well as ownership of assets and liabilities. Further, we identify some of the explanatory factors of the intra-household wealth gap and examine the role of the intra-partnership financial decision-making 
in explaining this gap. For this purpose, we regress the intra-partnership wealth gap on various explanatory variables in both OLS and multinomial logit models. Finally, we investigate whether the intra-partnership gap declines with a more equal bargaining power within the household.

The paper is structured as follows: Section 2 contains an overview of the literature. Section 3 reviews the data and the empirical strategy. Section 4 discusses the empirical results, and Section 5 provides conclusions.

\section{Related Literature}

Population surveys typically collect wealth information at the household level as reported by the reference person (typically defined as the household head, although not always). This is the case in surveys such as the Survey of Consumer Finances (SCF), the Spanish Survey of Household Finances (EFF), the Bank of Italy's Survey on Household Income and Wealth (SHIW) to name a few. However, this means of collecting wealth information does not allow the wealth distribution to be examined either within households or by gender. Thus, when trying to identify wealth differences by gender, for example, studies typically limit the focus to one-person households only (e.g., Schmidt and Sevak 2006, Yamokoski and Keister 2006, Chang 2010). Alternatively, studies focus on single wealth components where data is available at the individual level such as pension wealth (see Warren 2006). The common problem faced by studies using household-level wealth data is that it is not possible to determine asset ownership by particular individuals within married couples. Consequently, there has been little effort at decomposing wealth differentials by gender and there is not much that can be said about the financial well-being of married women (with respect to wealth holdings) even though a growing number of economic studies have emphasized the importance of looking at intra-household inequality (e.g., Haddad and Kanbur 1990; Woolley 1993, Allmendinger et al. 2006, Deere and Doss 2006).

Only a few studies to date have examined the distribution of wealth within households. Frick et al. (2007), for example, show that inequality is higher when individual-level data are used instead of household-level data. Given that household-level data implicitly assume an equal distribution of resources within the household, this creates a downward bias on inequality measures. The same authors also find that an increase in inequality based on standard inequality measures is higher for wealth than for income. This indicates that by using householdlevel data for wealth one assumes an even greater redistribution within the household than when using income measures. Considering that many countries have an equal split of assets in case of divorce, it is possible that the issue of within-household inequality is not seen as a crucial topic for some. However, the question of whether the threat point of individual economic well-being within a marriage is divorce or perhaps non-cooperation remains unanswered. For the latter case, higher relative ownership of assets and thus a lower wealth gap within the household would increase the bargaining situation within the household (Lee and Pocock 2007).

In order to explain the size of the gap within households we review the literature on within household income variation. This branch of literature (e.g., Pahl 2000) puts forward several factors for variation in couples' relative earnings. In the US, race is a good predictor of higher female contributions to family income as black women have higher labor force attachment than white women, and black men are the most disadvantaged group in the labor force. Winslow-Bowe (2006) finds that women with a college education are more likely to have a temporary or persistent earnings advantage over their male partners (regardless of the male's education) then less edu- 
cated women. On the other hand, more women than men work in part-time jobs, where the pay per hour is lower than for full-time work.

In terms of the gender wealth gap, Sierminska et al. (2010) show-for all men and women — that a wealth gap between women and men exists prior to marriage. Partners enter marriage with different levels of wealth because of age (typically men in Germany are 3 years older, see Sierminska et al. 2010), men have higher earnings, and their labor market participation is higher (Blau and Kahn 2000). This gives rise to higher wealth accumulation for men than for women. The wealth gap may be attenuated if women and men invest differently (Bajtelsmit and Bernasek 1996); men and women have different levels of risk tolerance (Jianakopolos and Bernasek 1998), different consumption and saving patterns (Fisher 2010), unequal credit conditions (Alesina et al. 2013), and also different inheritance patterns (Edlund and Kopczuk 2009).

We extend the findings of Sierminska et al. (2010) by focusing on wealth differences within partnerships in order to identify the true degree of inequality within households. Moreover, we examine the role of intra-partnership financial decision-making in the size of the gap. This is important as the financial decision-making process can reduce the wealth gap that may have existed before the marriage or before becoming partnered. Therefore, we hypothesize that, ceteris paribus, joint financial decision-making by couples is associated with a smaller intrahousehold wealth gap than sole responsibility of one partner-the man in particular-for household financial decisions. These hypotheses follow previous findings in the literature. For instance, Deere and Twyman (2012) show, that the woman's share of household wealth is positively and significantly associated with the likelihood of symmetry and agreement in joint decision-making by couples. However, findings from Bernasek and Bajtelsmit (2002) imply that women are more likely to influence financial decisions when they contribute a larger share to household income. Given that women's earnings are on average lower than men's, wealthier households show significantly less female involvement in financial decision-making. Another hypothesis has been presented by Amuedo-Dorantes et al. (2010), who argue that specialized traditional couples pool their incomes as a means of compensating for the household work performed by secondary earners. This type of quasi-wage transfer may reduce the intra-household wealth gap, but the research has yet to fully address how partners divide or share control of the assets between them. In one of the few studies on the subject, Chang (2010) reported that equal control of assets is very rare in couples. ${ }^{1}$

\section{Data and estimation strategy}

\subsection{Data}

We draw on data from the Socio-Economic Panel (SOEP), a representative longitudinal survey of individuals living in private households across Germany (Wagner et al. 2007). The survey started in 1984 in West Germany and was extended to include East Germany in 1990. At present, the SOEP consists of nine different subsamples including two oversamples of migrants and high-income households, of which the latter is crucial for this paper. Each household completes a household questionnaire and each individual household member over 17 years of age fills out an individual questionnaire. We use data from 2007, when more than 20,000 individuals in over

\footnotetext{
${ }^{1}$ Kan and Laurie (2010) report that there is a general downward trend for UK couples over the period 1995 to 2005 in joint holdings of savings, investments, and debts, "which may suggest a growing independence in financial arrangements between couple members over that period” (p. 1).
} 
10,000 households participated. We restrict the sample to cohabiting couples (independent of their marital status, hereafter referred to simply as couples) and are left with around 7,200 couples. ${ }^{2}$

\subsection{Outcome variable}

In 2007, the SOEP questionnaire included a special module focusing on individual wealth data, which are rare in surveys and crucial for our analyses. In this segment of the questionnaire, information is elicited for eight different asset and debt components: owner-occupied property (and associated debt), other property (and associated debt), building savings contracts, financial assets, life insurance policy (including private retirement insurance), business assets, valuable assets (including jewelry, gold, arts, etc.), and consumer loans. The data lack such asset components as durables, vehicles, and pension entitlements from public pension schemes. ${ }^{3}$ The SOEP wealth questionnaire did not survey children below 18, which should not distort our results since we focus on cohabitating couples (and because wealth holdings by children are presumably rather small). A more serious problem in collecting wealth data at the micro-level is measurement error from various sources such as rounding, misreporting and non-response (see, e.g., Riphahn and Serfling 2005). On the one hand, asking all adult household members separately instead of a single household representative may increase the accuracy of the true wealth holdings of each individual. On the other hand, this increases the probability of item-non-response on at least one single wealth component within the household and the risk of inconsistent information (e.g., two partners providing non-matching information on the very same issue, such as a commonly owned home). Coping with all these measurement problems is a major task. In the case of the SOEP wealth data, inconsistencies have been addressed by means of editing on a case-wise basis, while missing data are corrected for by multiple imputation techniques, explicitly considering the potential selectivity of the underlying missing mechanisms (for a description of these procedures see Frick et al. 2010b). A comparison with corresponding information from national balance sheets, however, indicates that the SOEP wealth data perform rather well (Frick et al. 2010a).

Our main dependent variable is the intra-partnership wealth gap ${ }^{4}$ defined as the difference between the male partner's wealth and the female partner's wealth. Hence, a positive intra-partnership wealth gap indicates that the male possesses higher wealth than the female. In order to mitigate the effect of outliers, we apply a $0.1 \%$ top and bottom coding for individual net worth. As is the case for wealth (level) data, the distribution of the intrapartnership wealth gap is also highly skewed. To further mitigate the influence of outliers, we apply the inverse hyperbolic sine transformation (Johnson 1949) of the intra-partnership wealth gap for the multivariate regression analysis. Like the logarithmic transformation, the inverse hyperbolic sine transformation is also useful in dealing with skewed variables. However, unlike the logarithmic transformation, it can also handle negative values and zero values. Hence, the inverse hyperbolic sine transformation is often applied when outcome variables are both skewed and can also take on negative values (Burbridge et al. 1988). For instance, Pence (2006) investigates the

\footnotetext{
${ }^{2}$ Given the main focus of our research on analyzing the gender wealth gap within couples, we refrain from considering homosexual partnerships.

${ }^{3}$ Most survey data does not capture public pension entitlements as these are, for the most part, not known to the respondent. For the relevance of public pension entitlements in wealth inequality research, see Frick and Grabka (2013).

${ }^{4}$ We use wealth and net worth interchangeably in the paper. Net worth is defined as the difference between total assets and liabilities.
} 
effect of tax incentives on household savings. In another application of the inverse hyperbolic sine transformation, Burbridge et al. (1988) analyze how wealth varies with age and family characteristics.

\subsection{Explanatory variables}

We use five different sets of explanatory variables to explain the intra-partnership wealth gap. These sets include demographics, income, labor market information, inheritances and variables related to power in the partnership. The demographic variables include age and the difference in age (i.e., the male's age minus the female's age). These variables are in line with the life-cycle hypothesis (Modigliani 1966), which states that wealth increases over the lifetime up to retirement in order to smooth consumption. The larger the age difference between the two partners, the bigger the intra-partnership wealth gap as the male partner has had more time to accumulate wealth. We control for whether the couple has children. Given that a woman's propensity to spend income on family provisioning and children's nutrition is greater than a man's (Blumberg 1988), this reduces her ability to accumulate wealth and should increase the wealth gap. On the other hand, Grossbard-Shechtman (1984) argues that in particular mothers could be compensated for caring for children by quasi-wage transfers, which would reduce the wealth gap. Further demographic covariates encompass marital status as well as the length of marriage. We also include the migration status given that an immigrant typically has below-average wealth (Bauer et al. 2011), and the geographic region for East and West Germany, because the wealth accumulation process in the two regions has differed dramatically. We control for life events such as divorce or widowhood by including appropriate dummy variables. These events have been shown to have substantial effects on individual wealth levels (e.g., Wilmoth and Koso 2002). Finally, we control for the couple's position in the wealth distribution by considering the (inverse hyperbolic sine of the) couple's total net worth. ${ }^{5}$

To proxy for permanent income we use five-year averages of individual total income. We include the income of the female as well as the difference between the male's and the female's income. ${ }^{6}$ The total income measure consists of individual earnings, self-employment income, unemployment benefits, pensions, and private transfers received.

Variables related to the labor market comprise information for both spouses on the number of years in fulltime/part-time employment or unemployment as well as on self-employment status (yes/no) and civil servant status (yes/no). The latter indicator variable is of particular relevance in Germany as all wealth surveys show a pronounced wealth advantage for civil servants compared to other dependent employees (e.g., Frick et al. 2010a). We also include the years of education for the female partner and the difference between the spouses' years of education. The difference in education is to control for bargaining power within the household.

The fourth set of explanatory variables covers inheritances and gifts. These are the main elements of great fortune. Gale and Scholz (1994) report that inheritances account for at least 50\% of the net worth of American families. Thus, inheritances could play an important role in explaining the intra-partnership wealth gap. The

\footnotetext{
${ }^{5}$ The results are robust to including the square and the cubic of the inverse hyperbolic sine of the couple's total wealth.

${ }^{6}$ In the case that the income information is missing for some years, we only use the available years for the computation of the mean. All income information is transformed to 2005 euros.
} 
SOEP collects annual inheritance data, but only at the household level. However, in 2001, respondents were also asked to provide inheritance information at the individual level. We include two binary variables for each spouse to distinguish between past and more recent inheritances (one for inheritances before 1992, the other for those between 1992 and 2001). ${ }^{7}$ Furthermore, we include dichotomous variables for missing inheritance information as some individuals joined the survey after 2001 and, hence, did not provide this information. The shortcoming of the inheritance variables is that they do not consider more recent events.

The fifth set of explanatory variables includes proxy information on the distribution of power and control within a partnership. The distribution of these aspects within the household may have a significant impact on the intrapartnership wealth gap: Gender differences that are prevalent outside the household could be leveled out or even reinforced within the household. Differences in the labor market, for example, (in particular the gender earnings gap) may directly impact the overall gender wealth gap, but the access of men and women in partnerships to financial resources also depends on what happens to the money after it enters the household (Kenney 2006). Thus we make use of two variables that describe the financial decision-making process. These are the "last word in financial decisions" and "money management within the couple" variables. These serve as proxies for implementing power and orchestration power as described by Safilios-Rothschild (1976). The individual who has both implementation and orchestration power within a partnership also has more control over financial resources and thus a higher probability of having more wealth than the other. If a joint decision process is arranged, one would assume a rather small intra-partnership wealth gap, which might be the result of wealth differences that existed before the individuals formed a couple. ${ }^{8}$ However, with the variables on distribution of power and control within a partnership, problems of reverse causality might occur, given that higher wealth may also result in a different distribution of responsibilities for money management within a couple (granting more power to the main earner). Therefore, we will not include variables on financial decision-making and money management in our main specification, but in an additional regression. ${ }^{9}$ In addition to the reverse causality issue, the coefficients of the financial decision-making and money management variables might be biased due to unobserved variables that affect the distribution of power and control within a partnership and that are also correlated with the actual wealth gap (e.g. the ex-ante wealth difference).

For the financial decision-making variables, we take advantage of two questions contained in the SOEP survey. The first variable is constructed from the question "Who has the last word in your relationship when making important financial decisions?”. Answers include "Me”, "my partner”, and "both of us equally”. The money management variables are based on the question "How do you and your partner decide what to do with the income that one of you or both receive?”. There are five answer options: separate money management, pooled

\footnotetext{
${ }^{7}$ We refrain from considering the amount of an inheritance/bestowal in order to avoid any assumptions about appreciation (e.g., appreciation differs for property and financial assets) and investment patterns given the timing of inheritances and correction of item-non-response. We do perform robustness checks with uncorrected amount variables (see Section 4.2.1)

${ }^{8}$ It should be noted that managing the money in a couple does not necessarily imply controlling the financial resources (Pahl 1995). We also find this to be the case in our data based on the two variables ("last word in financial decisions" and "money management").

${ }^{9}$ An explicit treatment of financial decision-making in Italy can be found in Bertocchi et al (2012).
} 
money management, partly pooled and partly separate money management, I manage, and partner manages. ${ }^{10}$ We only use the information for the female partner on power variables. If the woman does not provide information on the power variables, we utilize the man's answer. ${ }^{11}$

\subsection{Estimation strategy}

Our empirical analysis consists of two main parts. In the first part, we provide descriptive statistics for the size of the intra-partnership wealth gap as well as bivariate associations with some key explanatory variables. Here, we also look at the couples' total wealth holdings. All descriptive findings are analyzed from the perspective of the female and weighted with the survey weight of the female. The second part of the empirical section comprises multivariate analyses of the wealth gap. Here, we examine whether the bivariate associations remain in place after controlling for further variables. We estimate the following equation:

$$
I P G_{i}^{a s i n h}=\alpha+\beta X_{i}+\varepsilon_{i}
$$

where $I P G_{i}^{a s i n h}$ denotes the (inverse hyperbolic sine transformed) difference between the wealth holding of the male and the female partner in couple $i, \alpha$ is an intercept, $\varepsilon_{i}$ a random error term. $X_{i}$ include the explanatory variables, which we include in a stepwise fashion in the regression, as described in section 3.3. We estimate these equations by Ordinary Least Squares (OLS) and compute robust Huber-White standard errors. As there might be omitted variables, i.e., variables that are correlated with both $X_{i}$ and $\varepsilon_{i}$, we do not want to give our estimates a causal interpretation. Given that little research is available despite its importance (see also section 2), identifying factors that are associated with increases or decreases in the wealth gap is seen as a first step in this field. Identifying the causes of the wealth gap is an area for future research.

\section{Empirical analysis}

This section provides both descriptive (section 4.1) and multivariate analyses on the wealth gap within couples (section 4.2). The latter consists of three parts. First, a multivariate analysis of the wealth gap within couples is performed (as described in section 3.4), where the explanatory variables are considered stepwise. Next, we perform robustness checks of the preferred OLS model, and finally, we examine an alternative, more flexible, specification of the intra-partnership wealth gap.

\subsection{A description of the wealth gap within couples}

In this section, we summarize the results that can be found in Grabka et al. (2013). The mean difference in net worth between men and women within a partnership is about 33,000 euros. If one relates the mean wealth of

\footnotetext{
${ }^{10}$ The original wording of the five answer categories is a) Everyone looks after their own money, b) We put the money together and both of us take what we need, c) We put a share of the money together, and both of us keep a share of it for ourselves, d) I look after the money and provide my partner with a share of it, e) My partner looks after the money and provides me with a share of it.

${ }^{11}$ One cannot assume a perfect match of the answers by both partners. However, there is a large overlap. For robustness purposes we considered different codings of the power variables. We used a) only the male partner's information, b) the woman's answer and an additional dummy variable indicating a deviating answer of the man, and c) only the information of couples without contradictions. For all these codings the results did not change meaningfully. In terms of financial decision-making, the highest overlap of about $95 \%$ can be found for those stating that both have the last word. If the female answer that the partner has the last word, there is an overlap of at least $70 \%$. While if she declares to have the last word the accordance is about $67 \%$. For the latter two groups about $27 \%$ of the male partners have the opinion that a joint decision-making process is taking place. There is also no full overlap between the answers of both partners with respect to money management. The share of overlaps varies from $76 \%$ for part of money is shared to $95 \%$ for all money is shared.
} 
women to the mean couple's total wealth, this corresponds to a share of only $37 \%$. However, as seen in table 1 , men in partnerships do not always possess more wealth than women do. Whereas $19 \%$ of all couples have equal net worth—often no net worth at all—in at least $29 \%$ of the couples, the female has greater net worth than her partner. Here, the mean intra-partnership wealth gap amounts to more than -48,000 euros (-14,000 at the median) with women having about 104,000 euros net worth—more than twice as much as their male partner. The remaining share of couples (52\%) consists of males having more wealth than their female partner with a mean wealth gap of nearly 91,000 euros (25,000 euros at the median). The mean net worth of male partners, in this case, sums up to 183,000 euros, which is also twice as much as the mean net worth of their female counterparts.

In couples with equal mean net worth, the mean value of total net worth is the smallest at about 100,000 euros. However, this is the result of a share of $9 \%$ of couples having zero wealth. If one excludes these couples, the respective figure for the remaining couples is 193,000 euros, which is still more than in couples where the female partner has more wealth than her partner (153,000 euros only). The highest total net worth of more than 213,000 euros can be found in couples where the male partner has more wealth than his female partner. If he dies, his partner could profit from his bequeathed wealth. However, during marriage, this wealth gap might affect intra-household bargaining.

According to the life-cycle hypothesis (Modigliani 1966), wealth increases over the lifetime up to retirement and then decreases as individuals begin to decumulate their assets in order to smooth consumption. Putting aside cohort effects for a moment, this pattern can be confirmed for German couples. ${ }^{12}$ Women's wealth as a share of couple's wealth increases more or less continuously throughout the age distribution from $18 \%$ for the youngest age group up to $42 \%$ for those in the oldest age group of 76 years old and above. It may be the case that in more recently formed couples, financial affairs are organized separately, while in longer lasting relationships, couples tend to save more evenly and pool their wealth (Klawitter 2008). Another explanation may be that older women in couples with a traditional division of labor are better compensated for their work within the home (GrossbardShechtman 1993).

It has been shown that one of the sources of differential wealth accumulation between women and men comes from gender differences in the labor force. These include significant differences in labor market participation between women and men as well as a pronounced gender wage gap (e.g., Blau and Kahn 2000). Table 2 shows that women with more labor market experience accrue more wealth, and that women with at least 35 years of work experience have the smallest wealth gap. Here, the difference between the two sexes amounts to only 13,000 euros. For female workers with between 5 and 19 years of labor force participation, this gap is more than 42,000 euros. For these women, the relatively large wealth gap might be explained by the prominence of the male breadwinner model in Germany, where women often suspend their labor market activity to raise children, while their male partners continue working. There is a particularly wide gap for women who have never participated in the labor market. These women have below-average wealth, but the intra-partnership wealth gap

\footnotetext{
${ }^{12}$ Cohort effects play a particular role between East and West Germany. The socialist German Democratic Republic prior to 1989 had a policy of gender equality granting women equal rights and equal obligations and resulting in a higher share of women employed full-time in East than in West Germany. These cultural differences could also translate into a gender wealth gap and, in fact, our findings confirm this. For those living in East Germany when the Berlin Wall came down, the mean intra-partnership wealth gap is less than 14,000 euros, while the respective figure for West Germans is roughly 39,000 euros.
} 
amounts to less than 25,000 euros. This finding might be the result of an age bias towards younger females, or a bias in terms of a low-paid male partner. Another possible explanation might be that these women are paid quasiwages by their husbands as compensation for doing housework, which enables them to accumulate more wealth than women with more labor market experience but lower quasi-wage transfers (Grossbard-Shechtman 1984). The ratio of women's wealth to couple's wealth remains quite constant and quite low (about 1/3) except for those couples with the longest labor market experience, for which the ratio is still less than $50 \%$.

Having children typically influences the labor market participation of women negatively in Germany, thus reducing the chances to accumulate wealth on their own. The wealth gap for couples with children under the age of 16 years is about 36,000 euros, while the respective value for couples without children is 20,000 euros. Considering the different wealth levels of couples with and without children (see, e.g., Yamokoski und Keister 2006), the ratio between women's wealth and couples' wealth is $40 \%$ for couples without children and $37 \%$ for couples with children.

Next, we consider differences in the intra-partnership wealth gap with respect to money management. About two-thirds of all females state that they share financial resources equally with their partner, but this does not directly translate into equal wealth holdings. Here the mean intra-partnership wealth gap is about 33,000 euros and does not differ from the population mean (table 3). A comparable wealth gap is observed for couples that share part of the money and for couples in which both manage money individually. The intra-partnership wealth gap is the highest (55,000 euros) if only the male partner manages the money, while the smallest intrapartnership wealth gap of less than 10,000 euros exists when the female manages the money by herself. The total net worth of these couples is also the lowest of all groups. Based on these results, it seems that only if there is little or no wealth that needs to be managed females tend to be the ones in charge of managing these resources (see also Pahl 2000). This again points to the problem of reverse causality for these variables.

\subsection{A multivariate examination of the wealth gap within couples}

Next, we analyze whether the bivariate relationships obtained in the previous section also hold in multivariate regressions. We first regress the wealth gap within partnerships on different sets of regressors (4.2.1) and perform several robustness checks (4.2.2.). Next, we present an alternative specification of the outcome variable that only takes into account the direction of the difference between the male's and the female's wealth holding in the partnership, but not the size of the difference (4.2.3).

\subsubsection{Determinants of the within-partnership wealth gap}

Table 4 shows the results of the multivariate analyses of the wealth gap within a partnership, defined as the inverse hyperbolic sine of the difference between the man's and the woman's wealth. The columns display the coefficients of the five sets of explanatory variables (demographics, income, labor market, inheritances, financial decision-making), which we include gradually.

The included set of demographic variables in specification (1) explains around 5\% of the wealth difference. Including further explanatory variables in the other specification only slightly affects the coefficients for the demographic variables. Only for East German men and children in the household the coefficients lose signifi- 
cance. In line with our descriptive findings, we find that the wealth gap diminishes with age for females. Being an immigrant deepens the intra-partnership wealth gap for women. These women are usually married to men who are better off than they are. For men, the gap is smaller if they come from abroad. Migration is associated with costs, and those who immigrate to Germany are typically less educated, have higher unemployment rates and below average earnings, which directly translate to lower levels of wealth (Bauer et al. 2011). Alternatively, as Grossbard et al. (2010) argue, in marriage markets migrants have to pay a compensating differential, which leaves men with less wealth and thus reduces the intra-partnership wealth gap.

If the female is a widow, there is a chance that she has received an inheritance from her late husband. At the same time, she may have incurred costs related to his illness and death and may have transferred money to his children. Overall, the coefficient has a negative but insignificant effect on the wealth gap. If the male partner is a widower, there is a strong positive effect that deepens the intra-partnership wealth gap. This suggests that the widowers tend to form new relationships with lower-wealth partners and that they are reluctant to pay transfers to their new partners. Being divorced has no significant effect for females, but there is a rather strong negative effect reducing the wealth gap for males, which is significant in the main specification. Divorce is expensive and carries with it additional expenses and financial obligations towards the previous spouse, which reduces the possibility to accumulate assets. In addition, those who are divorced often need to make higher quasi-wage transfers to the current partner given that divorcees are less demanded in marriage markets (Grossbard-Shechtman 1993, Zissimopoulos et al. 2013).

Having children is usually associated with lower levels of wealth for women than for childless adults. Thus we observe a negative and significant effect on the gap for females without children. This finding is only significant in our first specification, however, and disappears once income is controlled for.

Our basic regression model also considers the total net worth of both partners. As expected the intra-partnership wealth gap significantly increases with higher wealth levels. This could result, for example, from different risk attitudes and investment decisions as identified in the literature, but also, as discussed below, from the higher share of self-employed men at the top of the distribution, who accumulate substantially higher levels of wealth (Sierminska et al. 2010). Being unmarried, the length of marriage, and the age difference between the partners do not have any significant effect on the wealth gap within partnerships.

Our second factor in explaining the intra-partnership wealth gap is a proxy for permanent individual income (mean over five years). Here, we observe the expected effect: The higher the woman's income, the smaller the intra-partnership wealth gap. Regarding income differences between the two partners, there is a clear result that indicates that the wealth gap is reduced if the female makes more money than her partner. These two findings are robust for all stepwise regressions.

The third factor comprises labor market characteristics. Rather strong effects can be found if at least one of the partners is currently self-employed. For women this implies a reduction of the wealth gap, while if the male is self-employed, the gap widens. The self-employed are not covered by the statutory pension system in Germany, 
thus they are responsible for their own for old-age provision. ${ }^{13}$ This is typically done by investing in private pensions or property and of course in business assets. This investment behavior reinforces the gap between partners because our measure of wealth does not include any public pension entitlements. A longer phase of parttime employment for men reduces the chances of being able to save. Thus, the gender wealth gap decreases. However, part-time employment of women does not affect the gender wealth gap. This could be because women have often worked more in "household labor benefiting their spouse" and, as a result, received more wealth transfers. Examining the educational level of women—as measured by years of education—shows no significant effect on the wealth gap, although one obtains the expected negative sign. The same is true for civil servants.

In the fourth specification we control for inheritances received. This information was collected in the SOEP in 2001 and we therefore include a dummy variable (equal to 1) for those individuals who entered the survey in more recent waves. This dummy variable does not show any significant effect. Receiving an inheritance reduces the intra-partnership wealth gap for women and increases the gap for men. These are complementary findings and are robust across all specifications. The effect for more recent inheritances (after 1992) is stronger for women, which could indicate more successful management of the inheritance, thus reducing the wealth gap (Sierminska et al. 2010). ${ }^{14}$

Our last set of explanatory factors of the intra-partnership wealth gap is the decision-making process within a couple. This information was not surveyed in 2007 but in 2005. In 2006, however, another subsample of the SOEP was surveyed for which the information about financial decision-making is missing. Thus the regression model in column 5 comprises about 1,000 individuals fewer than in regression models 1-4. Although the results shown are interesting in themselves, there is the limitation of reverse causality. When the female has the last word in financial decisions, this has a negative albeit small (and statistically insignificant) association with the gap. On the other hand, when the man has the last word in financial matters, this is positively associated with an increased gap, i.e., the wealth gap is bigger than in couples with joint decision-making. With respect to money management within couples, we find that the wealth gap is significantly smaller if the female manages the money alone as compared to the reference category (all money shared). All other combinations show no significant results, but with expected signs. The results also hold when we include financial decision-making and money management separately.

\footnotetext{
${ }^{13}$ Business assets strongly contribute to the intra-partnership wealth gap. The mean value of business assets is 3,600 euros for all married and cohabiting women while this figure is 28,000 euros for all men. Thus, women only have $13 \%$ of the corresponding business assets of men. For all other wealth components, this proportion/ is much higher. Owner-occupied property is more equally distributed. Here, women have achieved a share of about $80 \%$ (54,000 euros compared to 67,000 euros). When we exclude the population of self-employed for a robustness check, the general results are confirmed. Similarly, the results are also robust to the exclusion of couples in which one of the spouses works as a civil servant.

${ }^{14}$ For a robustness check, we include the uncorrected logarithm of the amount of inheritances together with the year of the inheritance. The results indicate that, ceteris paribus, a $10 \%$ increase in inheritances of females decreases the wealth gap by more than $9 \%$. Conversely, the gap increases by about $8 \%$ for a $10 \%$ increase in the males inheritances. The coefficients of the other variables do not change meaningfully and the model fit improves slightly ( $\mathrm{R}^{2}$ increases by 0.003$)$. These results are available from the authors upon request.

In an additional robustness check we exclude information about age given that previous literature (e.g. Lundberg and Ward-Batts, 2000) used the age difference as a control for bargaining power within the household. However, the general results could be confirmed.
} 


\subsubsection{Robustness checks}

To check the sensitivity of our results we perform several robustness tests, where the reference regression model is column 4 (without variables controlling for financial decisions within couples). For the first robustness test, we exclude couples having zero wealth, given the obvious problems inherent in treating zero wealth as equal wealth. Although this excludes more than 400 couples (column 6), our results remain robust to this restriction. In a second robustness check, we restrict the population of interest to couples below the age of 65 years, which is the official retirement age in Germany (column 7). We do this in order to concentrate on the phase of life when wealth is typically accumulated. All in all, the results only change marginally compared to the main specification. Given the age cutoff, the woman's age, whether men are divorced, and whether they recently received an inheritance are all no longer significant. All other covariates reconfirm the findings from the main specification.

In a further robustness check, we follow the literature on the existence of marriages of equally dependent spouses (Nock 2001) and apply this to the wealth context. Given that individual income is one of the most important factors for regular saving, we restrict the sample to equally dependent couples in terms of individual income. This will allow us to better isolate the factors that contribute to the gap. We define equally dependent spouses as couples in which both partners contribute between $40 \%$ and $60 \%$ of total household income. In specification 8 , the significant findings presented above for demographic characteristics nearly all become insignificant. Only the overall level of total wealth of the couple and the age of the female remain significant, which can indicate wealth differences that predate marriage or the importance of cohort effects. Differences in labor force experience no longer provide an important contribution to explaining the wealth gap, with the exception of the experience of full-time employment for men. This information now becomes significant, indicating an increase in the wealth gap. One can assume that previously, this effect was hidden in the income information. Being selfemployed has become even more important. With respect to recent inheritances, there is no longer a significant effect for males, which could be the result of the smaller sample for this regression model.

In the last robustness check, we use an alternative specification of the dependent variable. So far, we used the (inverse hyperbolic sine of the) intra-partnership wealth gap. In specification 9, we take the male's share in total wealth as the outcome variable. The problem with this alternative outcome measure is that it is not clear how to handle couples with negative total wealth or couples in which one partner has negative wealth (because a higher share means higher wealth for positive wealth and lower wealth for negative wealth). In addition, zero wealth of couples as the denominator is not defined, for which reason we also exclude these observations. Thus, the overall number of observations is reduced by one-sixth compared to the base model. Nevertheless, most of the findings can be confirmed; additionally, some explanatory variables now become significant. This is true for the coefficients for being unmarried, educational level, the male partner's experience of unemployment or part-time work, as well as the dummy variables for not being asked the inheritance question, which captures new subsample members. As expected, the overall wealth level is no longer relevant in this specification. All in all, the applied robustness checks by and large support our findings from the base model (column 4).

\subsubsection{An alternative multivariate examination of the wealth gap within couples}

The multivariate examination of the wealth gap within couples presented above assumes a linear relationship between the covariates and the wealth gap. However, one could also assume that there are opposing effects if 
either the female or the male has more wealth than his/her partner; i.e., some covariates might increase the chance that the female has more wealth than the male and at the same time increase the chance that the male has more wealth than the female. Thus, we apply a multinomial logit with three groups in which the reference group is couples with equal net worth (19\% of the cases). The second group consists of couples in which the female has more wealth (29\%); the third and largest group (52\%) comprises couples in which the male partner has more wealth. ${ }^{15}$

Table 5 compares average marginal effects of the multinomial logit model with the OLS coefficients of our preferred specification, specification (4). A first result is that the explained variance increases to $12.5 \%$ compared to less than $10 \%$ in the OLS model, which may point to existing nonlinearities in the relationship between the covariates and the intra-partnership wealth gap.

Next, we focus on the results from the multinomial logit that are significantly different from each other, given the presented chi-2 test (last column of table 5). ${ }^{16}$ If the covariate in the OLS model shows a positive effect (an increase in the wealth gap), this corresponds to a negative effect for the probability that the female holds more wealth than her partner. Conversely, if a negative effect is given by the OLS model, the respective outcome in the multinomial model is also a negative probability that the male partner has more wealth than the female partner.

The multinomial logit regression confirms the OLS regression results for female migrants, widowhood, the overall wealth level, individual income, and whether one of the partners is self-employed. In principle, this also applies to the inheritance variables, which again indicate a prominent role played by inheritances in explaining wealth differences within couples for both women and men. One exception is the most recent inheritance for male partners. Here the Chi-2 test shows that the coefficients in the multi-nominal model are not significantly different from each other although the signs point in the right direction.

In the OLS regression, the female's experience of full-time and part-time employment has no significant effect on reducing the intra-partnership wealth gap. In contrast, the multinomial logit model suggests that higher labor force attachment over the life course makes it more likely for females to have more wealth than their male partners. Longer part-time work experience reduces the intra-partnership wealth gap for men in the OLS model and works in favor of women by suggesting a higher probability of higher female wealth in the multinomial model than for these women's partners. ${ }^{17}$

\footnotetext{
${ }^{15}$ We explicitly want to consider these three different groups that differ in qualitative terms. A quantile regression technique would subdivide the total population by percentiles only. We also run a multinomial logit where the reference group consists of couples where the individual wealth share varies between $40 \%$ and $60 \%$ of total couple's wealth in order to relax the strict assumption of having identical net worth. The main findings are confirmed. In an alternative specification we estimated an ordered probit model, which provided very similar results. ${ }^{16}$ The chi-2 test gives information whether the covariates from specification $\mathrm{F}>\mathrm{M}$ and $\mathrm{M}>\mathrm{F}$ are significantly different from each other.

${ }^{17}$ This finding could also reflect reverse causality, given that women with more wealth may persuade their partners to work less and do more housework.
} 
In a second step, we also discuss selected variables for which the Chi-2-test does not show statistically significant differences between the coefficients of the multinomial logit model. First, we point to variables referring to the marital status of the couples. For example, in the OLS model, we do not obtain a significant coefficient for not being married. In the multinomial logit, however, we find a higher probability that the male holds more wealth than the female when the couple is not married. This may point to the finding that partners already enter marriage/partnership with different wealth levels (Sierminska et al. 2010). In the OLS model for older females, the intra-partnership gap is reduced, while in multinomial logit models there is a significant negative effect of men having more wealth. This result could be interpreted as a markdown for older women, as older women tend to have a lower "value" in the marriage market compared to younger women and thus men need to have less wealth to counterbalance this. For women who are older than their partners, the probability of the male partner having higher wealth is positive, suggesting a smaller quasi-wage transfer (Grossbard-Shechtman 1993) within the couple. Another interesting finding is that the length of a marriage, ceteris paribus, does not exhibit a significant effect either in the OLS or in the multinomial logit model. Thus, one cannot speculate whether the gap is reduced with the length of marriage. Summing up, examining the intra-partnership wealth gap via an alternative dependent variable using multinomial logit models complements our OLS regression findings with some particular variations and additional insights.

\section{Conclusions}

In this paper, we examine the wealth gap within partnerships exploiting unique individual wealth data from the German Socio-Economic Panel collected in 2007. We find that in $29 \%$ of all couples, the female owns more net worth than her partner; in $19 \%$ of all partnerships there is parity between the wealth levels of the partners; and finally in $52 \%$ of all couples the male partner has more wealth. Overall, the intra-partnership wealth gap (defined as the difference between the male's and the female's wealth) for German couples amounts to about 33,000 euros in 2007.

We analyze several sets of variables that might explain the intra-partnership wealth gap (demographic, income, labor market information, inheritances, and variables related to the control over money in the partnership). We find that all five groups contribute to the explanation of the wealth gap within partnerships. The wealth gap is the smallest in low-wealth households where the woman has control over money management. The man makes most of the financial decisions in the richest households. Being self-employed and having recently received an inheritance also has strong effects on the wealth gap. If a woman [man] is self-employed or has received an inheritance, the male-female wealth gap within the household is reduced [increased]. Thus, our results indicate that in a couple where the female has strong bargaining power in terms of higher income, or has received inheritances, the probability to hold more wealth than her partner is higher. This follows the findings of Lee and Pocock (2007) that in the aforementioned situations, the female saves more in absolute amounts but also saves relatively more in her own account. If the female manages the money within a couple, the intra-partnership wealth gap is smaller, while if the male has the last word in financial issues, the gap increases. Quasi-wage transfers may play an important role in explaining the intra-partnership wealth differences as compensation for housework (Grossbard-Shechtman 1984). This applies in particular to mothers, those with low labor market experience, and men with part-time labor market experience. In this context, rules of the marriage market also have to be considered, where high demand is compensated by higher levels of wealth (e.g. for divorced individuals or migrants). 
One relevant aspect that we do not consider in our empirical analyses is financial literacy and risk behavior (Lusardi and Mitchell 2008, Fonseca et al. 2010). It is shown that men and women differ in their financial knowledge and that females tend to invest more conservatively. These differences translate into different wealth levels. We are also not able to control for saving motives, which also differ between sexes. Women might be predicted to save more than men because of their higher life expectancy and a higher probability to become in need of care without having a partner. Additionally, the presence of children within the household can have an effect on the saving behavior (Shek-wai Hui et al. 2011).

In this paper, we focus on net worth from real and financial assets only. If one considers pension entitlements from public pension schemes, the observed intra-partnership wealth gap would increase even further, given that the labor force participation and earnings are higher for males than for females. Further research may also examine in more detail the investment patterns between women and men in relation to their financial decision-making, which may also explain the gaps.

Also, we cannot account for the phenomenon of hiding money from a partner (Malapit 2012). Ashraf (2009) suggests that some partners may conceal part of their money while reporting joint control over financial resources. Finally, in this study we do not control for differences prior to the partnership given that we only had wealth information available for 2002 and 2007, with an insufficient number of observations of new partnerships. More longitudinal information would facilitate the analysis of causality, which might be particularly relevant for financial control variables. ${ }^{18}$

Are our findings a reason to be concerned? One may argue that even if there exists an intra-partnership wealth gap during marriage, both partners can profit from the usage of real assets, and in case of death the whole net worth devolves to the surviving partner. However, given that divorce rates are increasing in a majority of OECD countries, one can no longer rely on a long-lasting institution like marriage for economic security. Women's financial dependency also makes it more difficult for them to leave abusive relationships. In many countries, a divorce leads to an equal split of assets; that is, everything that was acquired during marriage is subject to division. ${ }^{19}$ However, as shown by Sierminska et al. (2010), men and women already enter marriage with markedly different levels of wealth and, in most cases, females tend to have significantly lower levels of net worth. A divorce is typically associated with costs that may further reduce wealth levels. In addition, the final act of divorce is often preceded by a period of non-cooperation within the marriage, which provides the opportunity for

\footnotetext{
${ }^{18}$ For example, separate money management might lead a woman to return to full-time employment sooner after giving birth than she would if the couple practices joint decision-making and would thus impact the individual wealth level (see also Kenney 2006). To analyze the causal relationship, one could think about instrumental variables, but finding an adequate (strong) instrument is a challenge. An alternative could be the use of randomized experiments, but our research setting does not allow for this possibility. Having longitudinal data at hand would of course enable us to analyze the change of individual and household wealth for new couples between 2002 and 2007 as a function of financial decision-making. However, we only have 59 cases in which information for both new partners is available.

${ }^{19}$ A special case could be debts. Even if only one partner holds a mortgage (which would be assigned in the questionnaire to that person only) in case of a divorce, banks usually force the other partner to amortize the outstanding debt.
} 
partners to dissolve or transfer assets out of the marriage, suggesting that direct control over assets and a negligible wealth gap is the preferred option for both partners.

\section{References}

Alesina, A.F.; F. Lotti and P.E. Mistrulli (2013): Do women pay more for credit? Evidence from Italy. Journal of the European Economic Association 11(S1), 45-66.

Allmendinger, J.; Gartner, H.; Ludwig-Mayerhofer, W. (2006). The allocation of money in couples: The end of inequality? Zeitschrift für Soziologie, 35(3), 212-226.

Amuedo-Dorantes, Catalina, Jens Bonke and Shoshana Grossbard (2010). Income pooling and household division of labor: Evidence from Danish couples. IZA Discussion Paper No. 5418.

Ashraf, N. (2009). Spousal control and intra-household decision making: An experimental study in the Philippines. American Economic Review, 99(4), 1245-1277.

Bajtelsmit, V. and A. Bernasek (1996). Why do women invest differently than men? Financial Counselling and Planning, 7, 1-10.

Bauer, Thomas K., Deborah A. Cobb-Clark, Vincent A. Hildebrand and Mathias G. Sinning (2011). A Comparative analysis of the nativity wealth gap. Economic Inquiry, 49(4), 989-1007.

Bernasek A. and Bajtelsmit V.L. (2002). Predictors of women's involvement in in household financial decisionmaking. Financial Counselling and Planning, 13, 39-47.

Bertocchi, Graziella \& Brunetti, Marianna \& Torricelli, Costanza, 2012. Is It Money or Brains? The determinants of intra-family decision power. IZA Discussion Paper 6648.

Blau, Francine D. and Lawrence M. Kahn (2000). Gender differences in pay. Journal of Economic Perspectives, 14(4), 75-99.

Blumberg, Rae Lesser (1988). Income under female versus male control: Hypotheses from a theory of gender stratification and data from the Third World. Journal of Family Issues, 9(1), 51-84.

Burbridge, John B., Lonnie Magee, and A. Leslie Robb (1988). Alternative transformations to handle extreme values of the dependent variable. Journal of the American Statistical Association, 83(401), 123-127.

Chang, Mariko Lin (2010). Fact Sheet: Women and wealth in the United States. Sociologists for Women in So$\begin{array}{llll}\text { ciety } & \text { Network } & \text { News } & \text { Vol. }\end{array}$ (http://www.socwomen.org/web/images/stories/resources/fact_sheets/fact_2-2010-wealth.pdf). Accessed January, 07, 2013.

Deere, Carmen Diana and Cheryl R. Doss (2006). The gender asset gap: What do we know and why does it matter? Feminist Economics, 12(1-2), 1-50.

Deere, Carmen Diana and Jennifer Twyman (2012). Asset ownership and egalitarian decision making in dualheaded households in Ecuador. Review of Radical Political Economics, 44(3), 313-320.

Edlund, L. and W. Kopczuk (2009).Women, wealth and mobility. American Economic Review, 99(1), 146-78, March.

Fonseca, Raquel, Kathleen Mullen, Gema Zamarro, and Julie Zissimopoulos (2010). What explains the gender gap in financial literacy? The role of household decision-making. Rand Labor and Population Working Paper Series, WR-762.

Fisher, Patti J. (2010). Gender differences in personal saving behaviors. Journal of Financial Counseling and Planning Education, 21(1), 14-24. 
Frick, Joachim R., Markus M. Grabka and Eva M. Sierminska (2007). Representative wealth data for Germany from the German SOEP: The Impact of methodological decisions around imputation and the choice of the aggregation unit. DIW Discussion Paper no. 562, Berlin, March.

Frick, Joachim R., Markus M. Grabka and Richard Hauser (2010a). Die Verteilung der Vermögen in Deutschland. Empirische Analysen für Personen und Haushalte. Forschung aus der Hans-Böckler-Stiftung Nr. 118, Berlin, Edition Sigma.

Frick, Joachim R., Markus M. Grabka and Jan Marcus (2010b). Editing und multiple Imputation der Vermögensinformation 2002 und 2007 im SOEP. DIW Data Documentation No. 51, Berlin September 2010.

Frick, Joachim R. and Markus M. Grabka (2013): Public pension entitlements and the distribution of wealth. In: Janet C. Gornick and Markus Jäntti (eds.): “Income Inequality: Economic Disparities and the Middle Class in Affluent Countries”. Stanford University Press, in Press.

Gale, William G. and John Karl Scholz (1994). Intergenerational transfers and the accumulation of wealth. Journal of Economic Perspectives, 8, 145-160.

Grabka, M.M., Marcus, J. \& Sierminska, E.M., 2013. Wealth distribution within couples and financial decision making. CEPS/INSTEAD Working Paper Series, 2013-02.

Grossbard-Shechtman, Amyra (1984). A theory of allocation of time in markets for labour and marriage. Economic Journal, 94, 863-882.

Grossbard-Shechtman, Shoshana (1993). On the economics of marriage: A theory of marriage, labor, and divorce. Boulder: Westview Press.

Shoshana Grossbard, Jose Ignacio Gimenez-Nadal and Jose Alberto (2010). Racial discrimination and household chores. IZA Discussion Paper No. 5345.

Haddad, L. and Kanbur, R. (1990). How serious is the neglect of intra-household inequality? Economic Journal, 100, 866-881.

Jianakopolos, N.A. and Bernasek, A. (1998). Are women more risk averse? Economic Inquiry, 36, 620-630.

Johnson N.L. (1949). Systems of frequency curves generated by methods of translation. Biometrika, 36, 149176.

Kan, M-Y. and Laurie, H. (2010). Savings, investments, debts and psychological well-being in married and cohabiting couples. Institute for social \& economic research (ISER), working paper no. 2010-42.

Kenney, Catherine T. (2006). The power of the purse. Allocative systems and inequality in couple households. Gender \& Society, 20(3), 354-381.

Klawitter, Marieka (2008). The effects of sexual orientation and marital status on how couples hold their money. Review of Economics of the Household, 6(4), 423-446.

Lee, Jungmin and Mark L. Pocock (2007). Intra household allocation of financial resources: Evidence from South Korean individual bank accounts. Review of Economics of the Household, 5, 41-58.

Lundberg, Shelly and Jennifer Ward-Batts (2000). Saving for retirement: Household bargaining and household net worth. Working Papers 0026, University of Washington, Department of Economics.

Lusardi, Annamaria and Olivia S. Mitchell (2008). Planning and financial literacy: How do women fare? American Economic Review: Papers \& Proceedings, 98(2), 413-417.

Malapit, H.J.L. (2012). Why do spouses hide income? The Journal of Socio-Economics, 41, 584-593. 
Modigliani, Franco (1966). The life cycle hypothesis of saving, the demand for wealth and the supply of capital, Social Research, (1966: Summer). Extracted from PCI Full Text, published by ProQuest Information and Learning Company.

Nock, S. L. (2001). The marriages of equally dependent spouses. Journal of Family Issues, 22(6), 755-775.

Pahl, Jan (1995). His money, her money: Recent research on financial organisation in marriage. Journal of Economic Psychology, 16, 361-376.

Pahl, Jan (2000). Couples and their money: Patterns of accounting and accountability in the domestic economy. Accounting, Auditing and Accountability Journal, 13(4), 502 - 517.

Pence, Karen (2006). The role of wealth transformations: An application to estimating the effect of tax incentives on saving. In: Contributions to Economic Analysis \&Policy, 5(1), Article 20.

Phipps, S. and Burton, P. (1995). Sharing within families: implications for the measurement of poverty among individuals in Canada. Canadian Journal of Economics, 28(1), 177 - 204.

Riphahn, R.T and O. Serfling (2005). Item non-response on income and wealth questions. Empirical Economics, 30(2), 521-538.

Safilios-Rothschild, Constantina (1976). A macro- and micro-examination of family power and love: An exchange model. Journal of Marriage and the Family 37 (May), 355-362.

Schmidt, L. and Sevak, P. (2006). Gender, marriage and asset accumulation in the United States. Feminist Economics, 12 (1-2), 139-166.

Shek-wai Hui, Taylor, Carole Vincent and Frances Woolley (2011). Challenges to Canda's retirement income system. Understanding gender differences in retirement saving decisions. Social Research and Demonstration Corporation (SRDC). http://www.srdc.org/uploads/gender_differences_en.pdf. Accessed January, 07, 2013.

Sierminska, Eva M., Joachim R. Frick and Markus M. Grabka (2010). Examining the gender wealth gap. Oxford Economic Papers, 62(4), 669-690.

Sunden, A. and B. Surette (1998). Gender differences in the allocation of assets in retirement savings plans. American Economic Review, 88(2), 207-211.

Wagner, G.G., J. Frick \& J. Schupp (2007).The German Socio-Economic Panel Study (SOEP) - Scope, evolution and enhancements. Schmollers Jahrbuch, 127(1), 139-169.

Warren, T. (2006). Moving beyond the gender wealth gap: On gender, class, ethnicity, and wealth inequalities in the United Kingdom. Feminist Economics, 12(1-2), 195 - 219.

Wilmoth, J and G. Koso (2002). Does marital history matter? Marital status and wealth outcomes among preretirement adults. Journal of Marriage and the Family, 64(1), 254-268.

Winslow-Bowe, S. (2006). The Persistence of Wives' Income Advantage. Journal of Marriage and Family, 68(4), 824-842.

Wolff, Edward N. (2002). Inheritances and wealth inequality, 1989-1998. American Economic Review Papers and Proceedings, 92(2), 260-264.

Woolley, F. (1993). The feminist challenge to neoclassical economics. Cambridge Journal of Economics, 17, 485-500.

Yamokoski, A. and L.A. Keister (2006). The wealth of single women: Marital status and parenthood in the asset accumulation of young baby boomers in the United States. Feminist Economics, 12(1-2), 167-194.

Zagorsky, J.L. (1999). Young baby boomers’ wealth. Review of Income and Wealth, 45(2), 135-156. 
Zissimopoulos, Julie M., Benjamin R. Karney and Amy J. Rauer (2013): Marriage and economic well being at older ages. Review of Economics of the Household, online first (http://link.springer.com/article/10.1007\%2Fs11150-013-9205-x). 


\section{Tables}

Table 1: Distribution of net worth within couples and mean intra-partnership wealth gap

\begin{tabular}{l|cccc} 
& $\begin{array}{c}\text { Population share } \\
\text { (in \%) }\end{array}$ & $\begin{array}{c}\text { Mean wealth gap } \\
\text { (in } € \text { ) }\end{array}$ & $\begin{array}{c}\text { Mean net worth of } \\
\text { couples (in } € \text { ) }\end{array}$ & $\begin{array}{c}\text { Mean net worth of cou- } \\
\text { ples (in } € \text { ) without cou- } \\
\text { ples having zero wealth }\end{array}$ \\
\hline $\mathrm{F}>\mathrm{M}$ & 29 & $-48,769$ & 153,479 & 153,479 \\
$\mathrm{~F}=\mathrm{M}$ & 19 & 0 & 102,116 & 192,971 \\
$\mathrm{~F}<\mathrm{M}$ & 52 & 90,978 & 213,800 & 213,800 \\
\hline Total & 100 & 33,444 & 175,326 & 192,565
\end{tabular}

Source: SOEPv27, only couples and cohabiting partners.

Table 2: Female labor market experience in years and mean net worth

\begin{tabular}{l|ccc} 
& $\begin{array}{c}\text { Mean net } \\
\text { worth of } \\
\text { women (in } € \text { ) }\end{array}$ & $\begin{array}{c}\text { Mean wealth } \\
\text { gap (in } € \text { ) }\end{array}$ & $\begin{array}{c}\text { Ratio women's } \\
\text { wealth to couple's } \\
\text { wealth (in \%) }\end{array}$ \\
\hline 0 years & 41,944 & 24,605 & 36 \\
1-4 years & 33,752 & 24,632 & 32 \\
5-9 years & 63,586 & 42,974 & 34 \\
10-19 years & 78,268 & 42,125 & 36 \\
20-34 years & 90,899 & 33,573 & 37 \\
35 years and more & 93,322 & 12,980 & 45 \\
\hline Total & 75,026 & 33,538 & 37
\end{tabular}

Source: SOEPv27, only couples and cohabiting partners.

Table 3: Money management and intra-partnership wealth gap

\begin{tabular}{l|ccc} 
& $\begin{array}{c}\text { Mean net worth of } \\
\text { women (in } € \text { ) }\end{array}$ & $\begin{array}{c}\text { Mean wealth gap } \\
\text { (in } € \text { ) }\end{array}$ & $\begin{array}{c}\text { Ratio women's } \\
\text { wealth to couple's } \\
\text { wealth (in \%) }\end{array}$ \\
\hline She manages money & 88,735 & 32,817 & 37 \\
Each manages separately & 65,176 & 9,274 & 46 \\
He manages money & 103,611 & 55,130 & 31 \\
All money shared & 70,687 & 32,834 & 38 \\
Part of money shared & 55,869 & 30,001 & 33 \\
\hline Total & 73,236 & 32,597 & 37
\end{tabular}

Source: SOEPv27, only couples and cohabiting partners. 
Table 4: Determinants of the wealth gap within the household (men-women)

\begin{tabular}{|c|c|c|c|c|c|c|c|c|c|}
\hline & $\begin{array}{c}\text { (1) } \\
\text { demogr. }\end{array}$ & $\begin{array}{c}(2) \\
+ \text { income }\end{array}$ & $\begin{aligned} & (3) \\
+ & \text { labor }\end{aligned}$ & $\begin{aligned} & (4) \\
+ & \text { inher. }\end{aligned}$ & $\begin{array}{c}\text { (5) } \\
\text { +fin. dec. } \\
\text { making. }\end{array}$ & $\begin{array}{c}\text { (6) } \\
\text { excl. } 0- \\
\text { wealth }\end{array}$ & $\begin{array}{c}\quad(7) \\
<\text { age } 65\end{array}$ & $\begin{array}{c}\text { (8) } \\
\text { equal. } \\
\text { depend. }\end{array}$ & $\begin{array}{c}(9) \\
\text { his share }\end{array}$ \\
\hline Age $^{f}$ & $\begin{array}{c}-0.065^{* * *} \\
(0.020)\end{array}$ & $\begin{array}{c}-0.047^{* *} \\
(0.020)\end{array}$ & $\begin{array}{c}-0.051^{* *} \\
(0.025)\end{array}$ & $\begin{array}{c}-0.051^{* *} \\
(0.025)\end{array}$ & $\begin{array}{c}-0.058^{* *} \\
(0.027)\end{array}$ & $\begin{array}{c}-0.059^{* *} \\
(0.028)\end{array}$ & $\begin{array}{l}-0.005 \\
(0.045)\end{array}$ & $\begin{array}{c}-0.124^{* *} \\
(0.051)\end{array}$ & $\begin{array}{c}-0.002^{* * *} \\
(0.001)\end{array}$ \\
\hline$\Delta$ Age & $\begin{array}{c}0.035 \\
(0.028)\end{array}$ & $\begin{array}{c}0.033 \\
(0.027)\end{array}$ & $\begin{array}{c}0.048 \\
(0.031)\end{array}$ & $\begin{array}{c}0.051 \\
(0.031)\end{array}$ & $\begin{array}{c}0.051 \\
(0.033)\end{array}$ & $\begin{array}{c}0.055 \\
(0.034)\end{array}$ & $\begin{array}{c}0.007 \\
(0.046)\end{array}$ & $\begin{array}{c}0.109 \\
(0.065)\end{array}$ & $\begin{array}{c}-0.001 \\
(0.001)\end{array}$ \\
\hline Migrant $^{\mathrm{f}}$ & $\begin{array}{l}1.454^{* * * *} \\
(0.476)\end{array}$ & $\begin{array}{l}1.373^{* * * *} \\
(0.468)\end{array}$ & $\begin{array}{l}1.415^{* * * *} \\
(0.464)\end{array}$ & $\begin{array}{l}1.232^{* * * *} \\
(0.460)\end{array}$ & $\begin{array}{l}1.206^{* * *} \\
(0.499)\end{array}$ & $\begin{array}{l}1.282^{* * *} \\
(0.507)\end{array}$ & $\begin{array}{l}1.121^{* * *} \\
(0.511)\end{array}$ & $\begin{array}{c}0.252 \\
(1.018)\end{array}$ & $\begin{array}{c}0.053^{* * * *} \\
(0.015)\end{array}$ \\
\hline Migrant $^{\mathrm{m}}$ & $\begin{array}{c}-1.723^{* * * *} \\
(0.483)\end{array}$ & $\begin{array}{c}-1.458^{* * * *} \\
(0.476)\end{array}$ & $\begin{array}{c}-1.509^{* * * *} \\
(0.473)\end{array}$ & $\begin{array}{c}-1.342^{* * * *} \\
(0.470)\end{array}$ & $\begin{array}{c}-1.550^{* * * *} \\
(0.511)\end{array}$ & $\begin{array}{c}-1.401^{* * * *} \\
(0.521)\end{array}$ & $\begin{array}{c}-1.259^{* * *} \\
(0.530)\end{array}$ & $\begin{array}{l}-1.570 \\
(1.071)\end{array}$ & $\begin{array}{l}-0.029 \\
(0.015)\end{array}$ \\
\hline East German ${ }^{\mathrm{f}}$ & $\begin{array}{l}-0.352 \\
(0.686)\end{array}$ & $\begin{array}{c}0.053 \\
(0.674)\end{array}$ & $\begin{array}{c}0.047 \\
(0.679)\end{array}$ & $\begin{array}{c}-0.042 \\
(0.686)\end{array}$ & $\begin{array}{c}0.051 \\
(0.741)\end{array}$ & $\begin{array}{l}-0.037 \\
(0.713)\end{array}$ & $\begin{array}{l}-0.134 \\
(0.728)\end{array}$ & $\begin{array}{l}-1.566 \\
(1.356)\end{array}$ & $\begin{array}{l}-0.013 \\
(0.022)\end{array}$ \\
\hline East German ${ }^{\mathrm{m}}$ & $\begin{array}{c}-1.587^{* *} \\
(0.692)\end{array}$ & $\begin{array}{l}-1.197 \\
(0.679)\end{array}$ & $\begin{array}{l}-1.073 \\
(0.682)\end{array}$ & $\begin{array}{l}-0.954 \\
(0.689)\end{array}$ & $\begin{array}{l}-1.111 \\
(0.744)\end{array}$ & $\begin{array}{l}-0.981 \\
(0.719)\end{array}$ & $\begin{array}{l}-0.840 \\
(0.733)\end{array}$ & $\begin{array}{l}1.217 \\
(1.371)\end{array}$ & $\begin{array}{l}-0.013 \\
(0.023)\end{array}$ \\
\hline No children & $\begin{array}{c}-1.391^{* * *} \\
(0.363)\end{array}$ & $\begin{array}{l}-0.506 \\
(0.364)\end{array}$ & $\begin{array}{l}-0.466 \\
(0.366)\end{array}$ & $\begin{array}{l}-0.463 \\
(0.364)\end{array}$ & $\begin{array}{l}-0.635 \\
(0.395)\end{array}$ & $\begin{array}{l}-0.502 \\
(0.387)\end{array}$ & $\begin{array}{l}-0.334 \\
(0.423)\end{array}$ & $\begin{array}{l}-0.372 \\
(0.700)\end{array}$ & $\begin{array}{l}-0.009 \\
(0.011)\end{array}$ \\
\hline Divorced $^{\mathrm{f}}$ & $\begin{array}{c}0.289 \\
(0.453)\end{array}$ & $\begin{array}{c}0.407 \\
(0.448)\end{array}$ & $\begin{array}{c}0.371 \\
(0.446)\end{array}$ & $\begin{array}{c}0.395 \\
(0.445)\end{array}$ & $\begin{array}{c}0.242 \\
(0.473)\end{array}$ & $\begin{array}{c}0.421 \\
(0.482)\end{array}$ & $\begin{array}{c}0.177 \\
(0.497)\end{array}$ & $\begin{array}{l}-0.025 \\
(0.880)\end{array}$ & $\begin{array}{c}0.021 \\
(0.014)\end{array}$ \\
\hline Divorced $^{\mathrm{m}}$ & $\begin{array}{l}-0.851 \\
(0.437)\end{array}$ & $\begin{array}{l}-0.733 \\
(0.430)\end{array}$ & $\begin{array}{l}-0.798 \\
(0.431)\end{array}$ & $\begin{array}{c}-0.924^{* *} \\
(0.430)\end{array}$ & $\begin{array}{l}-0.707 \\
(0.464)\end{array}$ & $\begin{array}{c}-0.957^{* *} \\
(0.470)\end{array}$ & $\begin{array}{l}-0.735 \\
(0.491)\end{array}$ & $\begin{array}{l}-0.943 \\
(0.857)\end{array}$ & $\begin{array}{l}-0.026 \\
(0.014)\end{array}$ \\
\hline Widowed $^{\mathrm{f}}$ & $\begin{array}{l}-1.407 \\
(0.986)\end{array}$ & $\begin{array}{l}-1.515 \\
(0.973)\end{array}$ & $\begin{array}{l}-1.721 \\
(0.980)\end{array}$ & $\begin{array}{l}-1.760 \\
(0.970)\end{array}$ & $\begin{array}{l}-1.291 \\
(1.046)\end{array}$ & $\begin{array}{l}-2.089 \\
(1.096)\end{array}$ & $\begin{array}{l}-1.941 \\
(1.351)\end{array}$ & $\begin{array}{l}-1.659 \\
(1.803)\end{array}$ & $\begin{array}{c}-0.066^{* *} \\
(0.033)\end{array}$ \\
\hline Widowed $^{\mathrm{m}}$ & $\begin{array}{c}2.778^{* * * *} \\
(0.903)\end{array}$ & $\begin{array}{c}2.565^{* * *} \\
(0.874)\end{array}$ & $\begin{array}{c}2.495^{* * *} \\
(0.871)\end{array}$ & $\begin{array}{c}2.342^{* * * *} \\
(0.854)\end{array}$ & $\begin{array}{c}2.845^{* * * *} \\
(0.896)\end{array}$ & $\begin{array}{c}2.644^{* * * *} \\
(0.927)\end{array}$ & $\begin{array}{l}2.513^{* * *} \\
(1.270)\end{array}$ & $\begin{array}{c}1.932 \\
(1.652)\end{array}$ & $\begin{array}{c}0.098^{* * * *} \\
(0.027)\end{array}$ \\
\hline Notmarried & $\begin{array}{c}0.228 \\
(0.442)\end{array}$ & $\begin{array}{c}0.277 \\
(0.437)\end{array}$ & $\begin{array}{c}0.183 \\
(0.442)\end{array}$ & $\begin{array}{c}0.186 \\
(0.445)\end{array}$ & $\begin{array}{c}0.455 \\
(0.510)\end{array}$ & $\begin{array}{c}0.269 \\
(0.480)\end{array}$ & $\begin{array}{c}0.063 \\
(0.473)\end{array}$ & $\begin{array}{c}0.960 \\
(0.829)\end{array}$ & $\begin{array}{c}0.044^{* * *} \\
(0.016)\end{array}$ \\
\hline Marriage (length) & $\begin{array}{c}0.019 \\
(0.019)\end{array}$ & $\begin{array}{c}0.002 \\
(0.019)\end{array}$ & $\begin{array}{l}-0.003 \\
(0.019)\end{array}$ & $\begin{array}{c}-0.004 \\
(0.019)\end{array}$ & $\begin{array}{c}0.004 \\
(0.021)\end{array}$ & $\begin{array}{l}-0.003 \\
(0.021)\end{array}$ & $\begin{array}{c}-0.038 \\
(0.025)\end{array}$ & $\begin{array}{c}0.019 \\
(0.037)\end{array}$ & $\begin{array}{c}0.001 \\
(0.001)\end{array}$ \\
\hline Wealth (asinh) & $\begin{array}{c}0.285^{* * *} \\
(0.017)\end{array}$ & $\begin{array}{c}0.275^{* * * *} \\
(0.018)\end{array}$ & $\begin{array}{c}0.266^{* * * *} \\
(0.019)\end{array}$ & $\begin{array}{c}0.265^{* * *} \\
(0.019)\end{array}$ & $\begin{array}{c}0.248^{* * * *} \\
(0.021)\end{array}$ & $\begin{array}{c}0.274^{* * *} \\
(0.021)\end{array}$ & $\begin{array}{c}0.279^{* * * *} \\
(0.021)\end{array}$ & $\begin{array}{c}0.201^{* * * *} \\
(0.039)\end{array}$ & $\begin{array}{c}0.003 \\
(0.003)\end{array}$ \\
\hline Income $^{f}$ & & $\begin{array}{c}-0.051^{* * * *} \\
(0.009)\end{array}$ & $\begin{array}{c}-0.045^{* * *} \\
(0.011)\end{array}$ & $\begin{array}{c}-0.042^{* * *} \\
(0.011)\end{array}$ & $\begin{array}{c}-0.034^{* * * *} \\
(0.011)\end{array}$ & $\begin{array}{c}-0.042^{* * *} \\
(0.011)\end{array}$ & $\begin{array}{c}-0.037^{* * *} \\
(0.011)\end{array}$ & $\begin{array}{l}-0.021 \\
(0.024)\end{array}$ & $\begin{array}{c}-0.001^{* * * *} \\
(0.000)\end{array}$ \\
\hline$\Delta$ Income & & $\begin{array}{c}-0.033^{* * * *} \\
(0.004)\end{array}$ & $\begin{array}{c}-0.027^{* * *} \\
(0.005)\end{array}$ & $\begin{array}{c}-0.028^{* * *} \\
(0.005)\end{array}$ & $\begin{array}{c}-0.030^{* * * *} \\
(0.005)\end{array}$ & $\begin{array}{c}-0.028^{* * * *} \\
(0.005)\end{array}$ & $\begin{array}{c}-0.027^{* * * *} \\
(0.005)\end{array}$ & $\begin{array}{c}-0.082^{* * *} \\
(0.041)\end{array}$ & $\begin{array}{c}-0.000^{* * * *} \\
(0.000)\end{array}$ \\
\hline Education $^{f}$ (years) & & & $\begin{array}{l}-0.100 \\
(0.064)\end{array}$ & $\begin{array}{l}-0.090 \\
(0.064)\end{array}$ & $\begin{array}{l}-0.121 \\
(0.069)\end{array}$ & $\begin{array}{l}-0.087 \\
(0.068)\end{array}$ & $\begin{array}{l}-0.069 \\
(0.080)\end{array}$ & $\begin{array}{c}-0.073 \\
(0.134)\end{array}$ & $\begin{array}{c}-0.005^{* * *} \\
(0.002)\end{array}$ \\
\hline$\Delta$ Education & & & $\begin{array}{l}-0.008 \\
(0.058)\end{array}$ & $\begin{array}{c}0.009 \\
(0.057)\end{array}$ & $\begin{array}{c}0.056 \\
(0.062)\end{array}$ & $\begin{array}{c}0.002 \\
(0.061)\end{array}$ & $\begin{array}{l}-0.042 \\
(0.072)\end{array}$ & $\begin{array}{l}-0.093 \\
(0.130)\end{array}$ & $\begin{array}{l}0.003^{* * *} \\
(0.002)\end{array}$ \\
\hline Exp. full-time ${ }^{\mathrm{f}}$ & & & $\begin{array}{l}-0.017 \\
(0.014)\end{array}$ & $\begin{array}{l}-0.018 \\
(0.014)\end{array}$ & $\begin{array}{l}-0.011 \\
(0.015)\end{array}$ & $\begin{array}{l}-0.021 \\
(0.015)\end{array}$ & $\begin{array}{l}-0.035 \\
(0.022)\end{array}$ & $\begin{array}{l}-0.016 \\
(0.036)\end{array}$ & $\begin{array}{l}-0.001 \\
(0.001)\end{array}$ \\
\hline Exp. full-time ${ }^{\mathrm{m}}$ & & & $\begin{array}{c}0.027 \\
(0.022)\end{array}$ & $\begin{array}{c}0.026 \\
(0.022)\end{array}$ & $\begin{array}{c}0.012 \\
(0.023)\end{array}$ & $\begin{array}{c}0.031 \\
(0.024)\end{array}$ & $\begin{array}{c}0.037 \\
(0.037)\end{array}$ & $\begin{array}{l}0.089^{* * *} \\
(0.045)\end{array}$ & $\begin{array}{c}0.001 \\
(0.001)\end{array}$ \\
\hline Exp. part-time ${ }^{f}$ & & & $\begin{array}{l}-0.029 \\
(0.018)\end{array}$ & $\begin{array}{c}-0.024 \\
(0.018)\end{array}$ & $\begin{array}{l}-0.016 \\
(0.019)\end{array}$ & $\begin{array}{l}-0.026 \\
(0.019)\end{array}$ & $\begin{array}{l}-0.028 \\
(0.027)\end{array}$ & $\begin{array}{c}0.003 \\
(0.050)\end{array}$ & $\begin{array}{c}-0.001^{* *} \\
(0.000)\end{array}$ \\
\hline Exp. part-time ${ }^{\mathrm{m}}$ & & & $\begin{array}{c}-0.131^{* *} \\
(0.055)\end{array}$ & $\begin{array}{c}-0.133^{* *} \\
(0.055)\end{array}$ & $\begin{array}{c}-0.127^{* *} \\
(0.063)\end{array}$ & $\begin{array}{c}-0.155^{* *} \\
(0.061)\end{array}$ & $\begin{array}{c}-0.169^{* *} \\
(0.079)\end{array}$ & $\begin{array}{c}0.012 \\
(0.098)\end{array}$ & $\begin{array}{l}-0.003 \\
(0.002)\end{array}$ \\
\hline Exp. Unempl. ${ }^{f}$ & & & $\begin{array}{c}-0.018 \\
(0.053)\end{array}$ & $\begin{array}{c}-0.008 \\
(0.052)\end{array}$ & $\begin{array}{c}0.021 \\
(0.057)\end{array}$ & $\begin{array}{c}-0.011 \\
(0.063)\end{array}$ & $\begin{array}{c}0.058 \\
(0.063)\end{array}$ & $\begin{array}{c}0.008 \\
(0.111)\end{array}$ & $\begin{array}{l}-0.000 \\
(0.002)\end{array}$ \\
\hline Exp. Unempl. ${ }^{\mathrm{m}}$ & & & $\begin{array}{c}-0.088 \\
(0.053)\end{array}$ & $\begin{array}{c}-0.090 \\
(0.053)\end{array}$ & $\begin{array}{c}-0.123^{* *} \\
(0.057)\end{array}$ & $\begin{array}{c}-0.138 \\
(0.074)\end{array}$ & $\begin{array}{l}-0.120 \\
(0.066)\end{array}$ & $\begin{array}{c}0.168 \\
(0.107)\end{array}$ & $\begin{array}{c}-0.008^{* * * *} \\
(0.003)\end{array}$ \\
\hline Self-employed ${ }^{\mathrm{f}}$ & & & $\begin{array}{c}-1.664^{* * * *} \\
(0.589)\end{array}$ & $\begin{array}{c}-1.681^{* * * *} \\
(0.587)\end{array}$ & $\begin{array}{c}-1.685^{* * * *} \\
(0.630)\end{array}$ & $\begin{array}{c}-1.684^{* * * *} \\
(0.592)\end{array}$ & $\begin{array}{c}-1.960^{* * * *} \\
(0.614)\end{array}$ & $\begin{array}{c}-4.130^{* * * *} \\
(1.269)\end{array}$ & $\begin{array}{c}-0.032^{* *} \\
(0.015)\end{array}$ \\
\hline Self-employed $^{\mathrm{m}}$ & & & $\begin{array}{c}3.112^{* * *} \\
(0.429)\end{array}$ & $\begin{array}{c}3.080^{* * * *} \\
(0.426)\end{array}$ & $\begin{array}{c}3.024^{* * *} \\
(0.455)\end{array}$ & $\begin{array}{c}3.100^{* * *} \\
(0.431)\end{array}$ & $\begin{array}{c}2.989^{* * *} \\
(0.446)\end{array}$ & $\begin{array}{c}4.713^{* * *} \\
(0.954)\end{array}$ & $\begin{array}{c}0.077^{* * *} \\
(0.011)\end{array}$ \\
\hline Civil servant ${ }^{\mathrm{f}}$ & & & $\begin{array}{l}-0.623 \\
(0.695)\end{array}$ & $\begin{array}{l}-0.666 \\
(0.694)\end{array}$ & $\begin{array}{l}-0.183 \\
(0.749)\end{array}$ & $\begin{array}{l}-0.660 \\
(0.699)\end{array}$ & $\begin{array}{l}-0.966 \\
(0.715)\end{array}$ & $\begin{array}{l}-1.501 \\
(1.173)\end{array}$ & $\begin{array}{l}-0.004 \\
(0.015)\end{array}$ \\
\hline Civil servant ${ }^{\mathrm{m}}$ & & & $\begin{array}{c}0.432 \\
(0.532)\end{array}$ & $\begin{array}{c}0.428 \\
(0.531)\end{array}$ & $\begin{array}{c}0.440 \\
(0.575)\end{array}$ & $\begin{array}{c}0.396 \\
(0.539)\end{array}$ & $\begin{array}{c}0.270 \\
(0.547)\end{array}$ & $\begin{array}{c}1.508 \\
(1.117)\end{array}$ & $\begin{array}{c}0.000 \\
(0.012)\end{array}$ \\
\hline Inherit. $>1992^{\mathrm{f}}$ & & & & $\begin{array}{c}-2.930^{* * * *} \\
(0.505)\end{array}$ & $\begin{array}{c}-2.901^{* * *} \\
(0.508)\end{array}$ & $\begin{array}{c}-2.932^{* * *} \\
(0.511)\end{array}$ & $\begin{array}{c}-3.145^{* * *} \\
(0.585)\end{array}$ & $\begin{array}{c}-4.611^{* * * *} \\
(1.065)\end{array}$ & $\begin{array}{c}-0.081^{* * *} \\
(0.012)\end{array}$ \\
\hline Inherit. $>1992^{\mathrm{m}}$ & & & & $\begin{array}{l}1.155^{* * *} \\
(0.484)\end{array}$ & $\begin{array}{l}1.082^{* *} \\
(0.489)\end{array}$ & $\begin{array}{l}1.177^{* * *} \\
(0.487)\end{array}$ & $\begin{array}{c}0.852 \\
(0.568)\end{array}$ & $\begin{array}{c}1.223 \\
(1.039)\end{array}$ & $\begin{array}{l}0.043^{* * * *} \\
(0.012)\end{array}$ \\
\hline
\end{tabular}


Table 4 continued ...

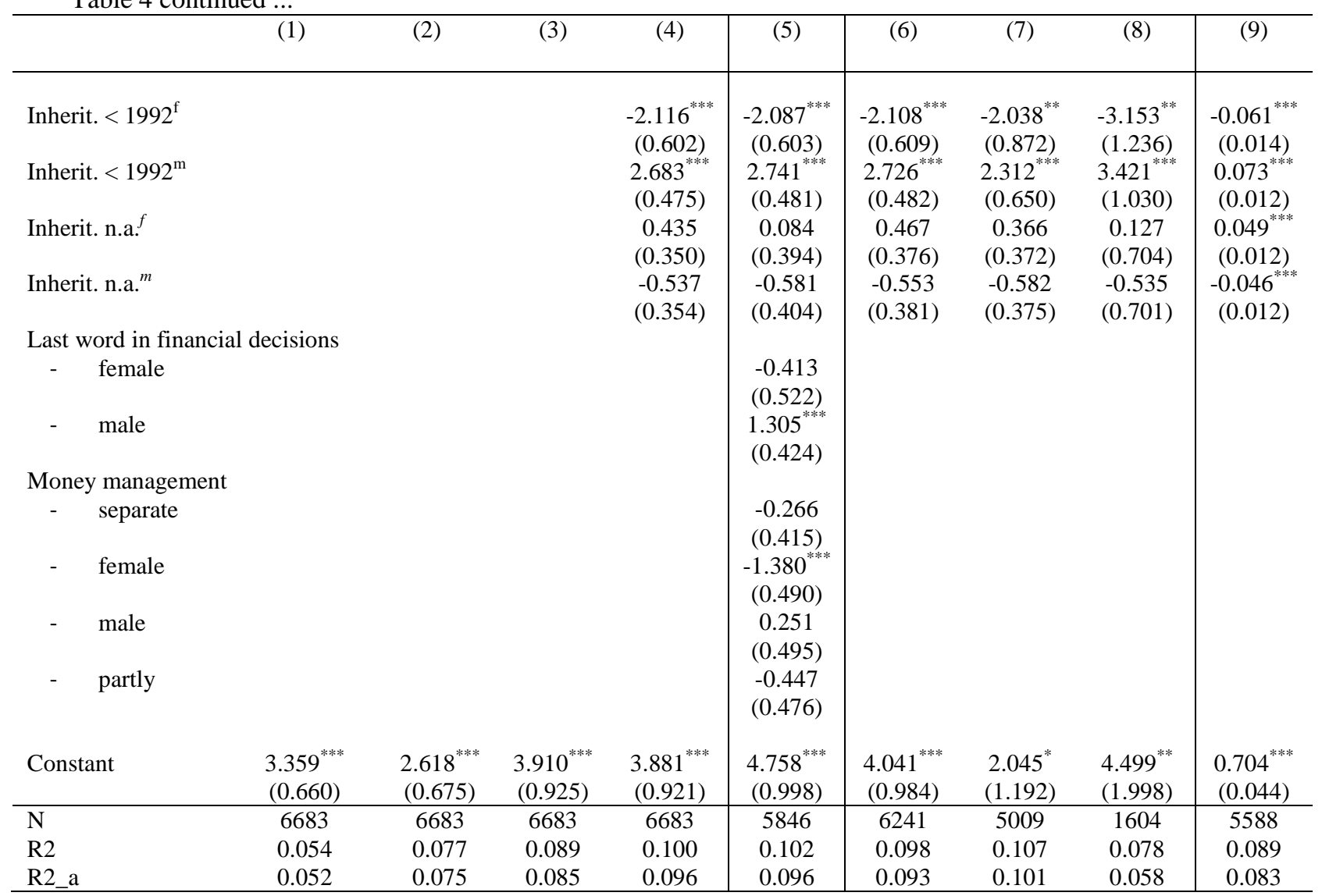

Source: SOEPv27, only couples and cohabiting partners.

Note: The table presents the coefficients of OLS regressions and their robust standard errors, where the outcome is the (inverse hyperbolic sine of the) difference between the wealth of the male and the wealth of the female. Specifications (1)-(5) stepwise include control variables, specification (6) exclude couples having zero wealth, (7) considers only couples where both are 65 or below, specification (8) only considers equally dependent spouses (in terms of income, 40-60 \%), and specification (9) takes the share of the man's share in the couple's wealth as outcome. " $f$ " [" $m$ "] means that the variable applies to the female [male], $\Delta$ denotes the difference between his and her value of the specific variable. ${ }^{* *} p<0.05,{ }^{* * *} p<0.01$ 
Table 5: Determinants of the wealth gap within the household (men-women OLS-regression) and marginal effects of a multinomial regression analysis

\begin{tabular}{|c|c|c|c|c|}
\hline & (1) & & (2) & \\
\hline & (OLS) & & MLOGIT & \\
\hline & & $\mathbf{F}>\mathbf{M}$ & $\mathbf{M}>\mathbf{F}$ & Chi2 \\
\hline $\operatorname{Age}^{f}$ & $-0.051^{* *}$ & -0.000 & $-0.004^{* * *}$ & 1.44 \\
\hline$\Delta$ Age & 0.051 & -0.001 & $0.005^{* * *}$ & 3.53 \\
\hline Migrant $^{\mathrm{f}}$ & $1.232^{* * *}$ & $-0.067^{* * *}$ & $0.050^{* *}$ & $6.68^{* * *}$ \\
\hline Migrant $^{\mathrm{m}}$ & $-1.342^{* * *}$ & 0.009 & $-0.084^{* * *}$ & 3.08 \\
\hline East German ${ }^{\mathrm{f}}$ & -0.042 & -0.000 & -0.002 & 0.00 \\
\hline East German ${ }^{\mathrm{m}}$ & -0.954 & 0.018 & -0.054 & 1.27 \\
\hline No children & -0.463 & 0.003 & -0.028 & 0.74 \\
\hline Divorced $^{\mathrm{f}}$ & 0.395 & -0.020 & 0.014 & 0.81 \\
\hline Divorced $^{\mathrm{m}}$ & $-0.924^{* *}$ & $0.040^{* *}$ & -0.029 & 3.49 \\
\hline Widowed $^{\mathrm{f}}$ & -1.760 & 0.067 & -0.084 & 3.02 \\
\hline Widowed $^{\mathrm{m}}$ & $2.342^{* * *}$ & $-0.090^{* *}$ & $0.110^{* *}$ & $5.51^{* *}$ \\
\hline Not married & 0.186 & 0.012 & $0.051^{* *}$ & 0.56 \\
\hline Marriage (length) & -0.004 & -0.001 & -0.001 & 0.01 \\
\hline Wealth (asinh) & $0.265^{* * *}$ & $-0.008^{* * *}$ & $0.019^{* * *}$ & $147.71^{* * *}$ \\
\hline Income $\mathrm{e}^{\mathrm{f}}$ & $-0.042^{* * *}$ & $0.002^{* * *}$ & $-0.001^{* * *}$ & $13.01^{* * *}$ \\
\hline$\Delta$ Income & $-0.028^{* * *}$ & $0.001^{* * *}$ & $-0.001^{* * *}$ & $23.02^{* * *}$ \\
\hline Education $^{\mathrm{f}}$ & -0.090 & $0.007^{* *}$ & -0.002 & 3.00 \\
\hline$\Delta$ Education & 0.009 & -0.003 & 0.000 & 0.38 \\
\hline Exp. full-time ${ }^{\mathrm{f}}$ & -0.018 & $0.002^{* *}$ & -0.001 & $4.17^{* *}$ \\
\hline Exp. full-time ${ }^{\mathrm{m}}$ & 0.026 & -0.000 & 0.002 & 0.49 \\
\hline Exp. part-time $\mathrm{f}^{\mathrm{f}}$ & -0.024 & $0.003^{* * *}$ & -0.001 & $5.65^{* *}$ \\
\hline Exp. part-time $^{\mathrm{m}}$ & $-0.133^{* *}$ & $0.007^{* *}$ & -0.005 & $4.88^{* *}$ \\
\hline Exp. Unempl. ${ }^{f}$ & -0.008 & -0.000 & -0.003 & 0.18 \\
\hline Exp. Unempl. ${ }^{\mathrm{m}}$ & -0.090 & 0.001 & $-0.015^{* * *}$ & 3.57 \\
\hline Self-employed $^{\mathrm{f}}$ & $-1.681^{* * *}$ & $0.099^{* * *}$ & -0.046 & $11.21^{* * *}$ \\
\hline Self-employed $^{\mathrm{m}}$ & $3.080^{* * *}$ & $-0.057^{* * *}$ & $0.165^{* * *}$ & $29.09^{* * *}$ \\
\hline Civil servant ${ }^{\mathrm{f}}$ & -0.666 & 0.035 & -0.020 & 1.17 \\
\hline Civil servant ${ }^{\mathrm{m}}$ & 0.428 & -0.011 & 0.017 & 0.38 \\
\hline Inherit. $>1992^{\mathrm{f}}$ & $-2.930^{* * *}$ & $0.122^{* * *}$ & $-0.098^{* * *}$ & $31.65^{* * *}$ \\
\hline Inherit. $>1992^{\mathrm{m}}$ & $1.155^{* *}$ & -0.019 & $0.048^{* *}$ & 2.14 \\
\hline Inherit. $<1992^{\mathrm{f}}$ & $-2.116^{* * *}$ & $0.094^{* * *}$ & $-0.082^{* * *}$ & $13.77^{* * *}$ \\
\hline Inherit. $<1992^{\mathrm{m}}$ & $2.683^{* * *}$ & $-0.077^{* * *}$ & $0.122^{* * *}$ & $18.20^{* * *}$ \\
\hline Inherit. n.a. ${ }^{f}$ & 0.435 & -0.020 & 0.014 & 1.30 \\
\hline Inherit. n.a. ${ }^{m}$ & -0.537 & 0.017 & -0.034 & 2.43 \\
\hline Constant & $3.881^{* * *}$ & & & \\
\hline $\mathrm{N}$ & 6683 & & 6683 & \\
\hline R2_adj / Pseudo R2 & 0.096 & & 0.125 & \\
\hline
\end{tabular}

Source: SOEPv27, only couples and cohabiting partners.

Note: The table presents for specification (1) the coefficients of OLS regressions, where the outcome is the (inverse hyperbolic sine of the) difference between the wealth of the male and the wealth of the female. This specification resembles specification (4) of the previous table. Specification (2) are average marginal effects of a multinomial regression with the reference group of equally dependent spouses (in terms of net worth of female=male). " $p$ ' [" $m$ "] means that the variable applies to the female [male], $\Delta$ denotes the difference between his and her value of the specific variable. ${ }^{* *} p<0.05, \stackrel{* * *}{p} p<0.01$ 
Appendix: Table 6: Descriptive statistics of covariates used in the OLS regression of the wealth gap within the household

\begin{tabular}{|c|c|c|c|c|c|}
\hline Variable & Obs & Mean & Std. Dev. & Min & Max \\
\hline Wealth gap (asinh) & 6683 & 2.519 & 9.528 & -14.431 & 14.454 \\
\hline $\operatorname{Age}^{\mathrm{f}}$ & 6683 & 50.074 & 14.569 & 18.000 & 91.000 \\
\hline$\Delta$ Age & 6683 & -2.740 & 4.592 & -47.000 & 22.000 \\
\hline Migrant $^{\mathrm{f}}$ & 6683 & 0.128 & 0.334 & 0.000 & 1.000 \\
\hline Migrant $^{\mathrm{m}}$ & 6683 & 0.126 & 0.332 & 0.000 & 1.000 \\
\hline East German ${ }^{\mathrm{f}}$ & 6683 & 0.265 & 0.441 & 0.000 & 1.000 \\
\hline East German ${ }^{\mathrm{m}}$ & 6683 & 0.255 & 0.436 & 0.000 & 1.000 \\
\hline No children & 6683 & 0.144 & 0.351 & 0.000 & 1.000 \\
\hline Divorced $^{\mathrm{f}}$ & 6683 & 0.132 & 0.338 & 0.000 & 1.000 \\
\hline Divorced $^{\mathrm{m}}$ & 6683 & 0.137 & 0.344 & 0.000 & 1.000 \\
\hline Widowed $^{\mathrm{f}}$ & 6683 & 0.020 & 0.140 & 0.000 & 1.000 \\
\hline Widowed $^{\mathrm{m}}$ & 6683 & 0.022 & 0.145 & 0.000 & 1.000 \\
\hline Not married & 6683 & 0.116 & 0.320 & 0.000 & 1.000 \\
\hline Marriage (length) & 6683 & 22.250 & 16.830 & 0.000 & 67.000 \\
\hline Wealth (asinh) & 6683 & 9.929 & 6.368 & -12.899 & 15.124 \\
\hline Income $\mathrm{e}^{\mathrm{f}}$ & 6683 & 14.718 & 15.617 & 0.000 & 379.951 \\
\hline$\Delta$ Income & 6683 & -21.346 & 32.743 & -483.620 & 308.577 \\
\hline Education $^{\mathrm{f}}$ (years) & 6683 & 12.089 & 2.616 & 7.000 & 18.000 \\
\hline$\Delta$ Education & 6683 & -0.436 & 2.512 & -11.000 & 11.000 \\
\hline Exp. full-time ${ }^{\mathrm{f}}$ & 6683 & 13.082 & 11.552 & 0.000 & 50.000 \\
\hline Exp. full-time ${ }^{m}$ & 6683 & 26.320 & 12.301 & 0.000 & 58.000 \\
\hline Exp. part-time ${ }^{\mathrm{f}}$ & 6683 & 5.504 & 7.554 & 0.000 & 44.000 \\
\hline Exp. part-time ${ }^{m}$ & 6683 & 0.636 & 2.085 & 0.000 & 41.000 \\
\hline Exp. unempl. ${ }^{\mathrm{f}}$ & 6683 & 0.879 & 2.104 & 0.000 & 26.000 \\
\hline Exp. unempl. ${ }^{\mathrm{m}}$ & 6683 & 0.802 & 1.982 & 0.000 & 35.000 \\
\hline Self-employed ${ }^{\mathrm{f}}$ & 6683 & 0.051 & 0.219 & 0.000 & 1.000 \\
\hline Self-employed $^{\mathrm{m}}$ & 6683 & 0.095 & 0.293 & 0.000 & 1.000 \\
\hline Civil servant ${ }^{\mathrm{f}}$ & 6683 & 0.041 & 0.197 & 0.000 & 1.000 \\
\hline Civil servant ${ }^{\mathrm{m}}$ & 6683 & 0.063 & 0.243 & 0.000 & 1.000 \\
\hline Inherit. > $1992^{\mathrm{f}}$ & 6683 & 0.071 & 0.257 & 0.000 & 1.000 \\
\hline Inherit. $>1992^{\mathrm{m}}$ & 6683 & 0.067 & 0.250 & 0.000 & 1.000 \\
\hline Inherit. $<1992^{\mathrm{f}}$ & 6683 & 0.050 & 0.217 & 0.000 & 1.000 \\
\hline Inherit. $<1992^{\mathrm{m}}$ & 6683 & 0.067 & 0.250 & 0.000 & 1.000 \\
\hline Inherit. n.a. ${ }^{f}$ & 6683 & 0.281 & 0.450 & 0.000 & 1.000 \\
\hline Inherit. n.a. ${ }^{\mathrm{m}}$ & 6683 & 0.279 & 0.449 & 0.000 & 1.000 \\
\hline $\begin{array}{l}\text { Last word in financ } \\
\text { sions }\end{array}$ & & & & & \\
\hline - female & 5852 & 0.061 & 0.239 & 0.000 & 1.000 \\
\hline - male & 5852 & 0.088 & 0.283 & 0.000 & 1.000 \\
\hline Money managemen & & & & & \\
\hline - separate & 5854 & 0.149 & 0.356 & 0.000 & 1.000 \\
\hline - female & 5854 & 0.066 & 0.249 & 0.000 & 1.000 \\
\hline - male & 5854 & 0.064 & 0.244 & 0.000 & 1.000 \\
\hline - $\quad$ partly & 5854 & 0.084 & 0.277 & 0.000 & 1.000 \\
\hline
\end{tabular}

Source: SOEPv27, only couples and cohabiting partners. 


\section{Acknowledgment}

The authors would like to thank Francesco Figari, Adam Lederer, Deborah Anne Bowen, the participants of the 2012 IARIW conference, the 2013 ECINEQ conference, 2013 ESA conference, two anonymous referees and the editor Shoshana Grossbard for helpful suggestions and comments.

\section{Funding}

Markus M. Grabka thanks the Hans-Boeckler-Foundation for the project on 'Vermögen in Deutschland. Status quo-Analysen und Perspektiven’ (HBS-Project-Nr. 2012-610-4).

\section{Conflict of interest}

The authors declare that they have no conflict of interest. 